\title{
KONSEP PERNIKAHAN MASYARAKAT SAMIN DAN PENDEKATAN DAKWAH KULTURAL
}

\author{
ALI DAMSUKI \\ Pascasarjana UIN Walisongo Semarang \\ Email: aly.damzuqy@gmail.com
}

\begin{abstract}
$T$ he human patterns and behavior in the dynamics of society have internal uniqueness in forming a habit. The pattern and behavior become a social construction that tends to humanist values so that it has implications for culture. Culture is the result of human creativity, initiative, and taste. Culture represents a distinctive feature for people living in an area. The Samin community remains a group that adheres to the teachings of Saminism. In the Samin community, the culture of the wedding ceremony is contrary to Islam. There are so many things deviate from Islamic ways, such as the term "weton" (birthday) which is frequently used as the fundamental tendency for the Samin community in determining marriage mates, days and dates of marriage in a Javanese perspective and do not involve the KUA in the marriage procession. In Islam, marriage unlimited to the symbol of the birthday of every couple, both male and female. This is explained in al-Dzariyat: 49. After the presence of Islam as a religion of da'wah, the culture of the Samin community began to experience systematic changes, both religious and nationalist through the propagation of empowerment with a cultural approach. Empowerment of da'wah with a cultural approach gradually began to come into contact with the culture of the Samin community which tended to be "conservative." This change occurred through the acculturation of Samin's Islamic marriage culture and administrative records by KUA. These changes occur through the acculturation of the culture of Samin's Islamic marriage and administrative records by the KUA.
\end{abstract}

Keyword: da'wah of culture, wedding ceremony, Samin community

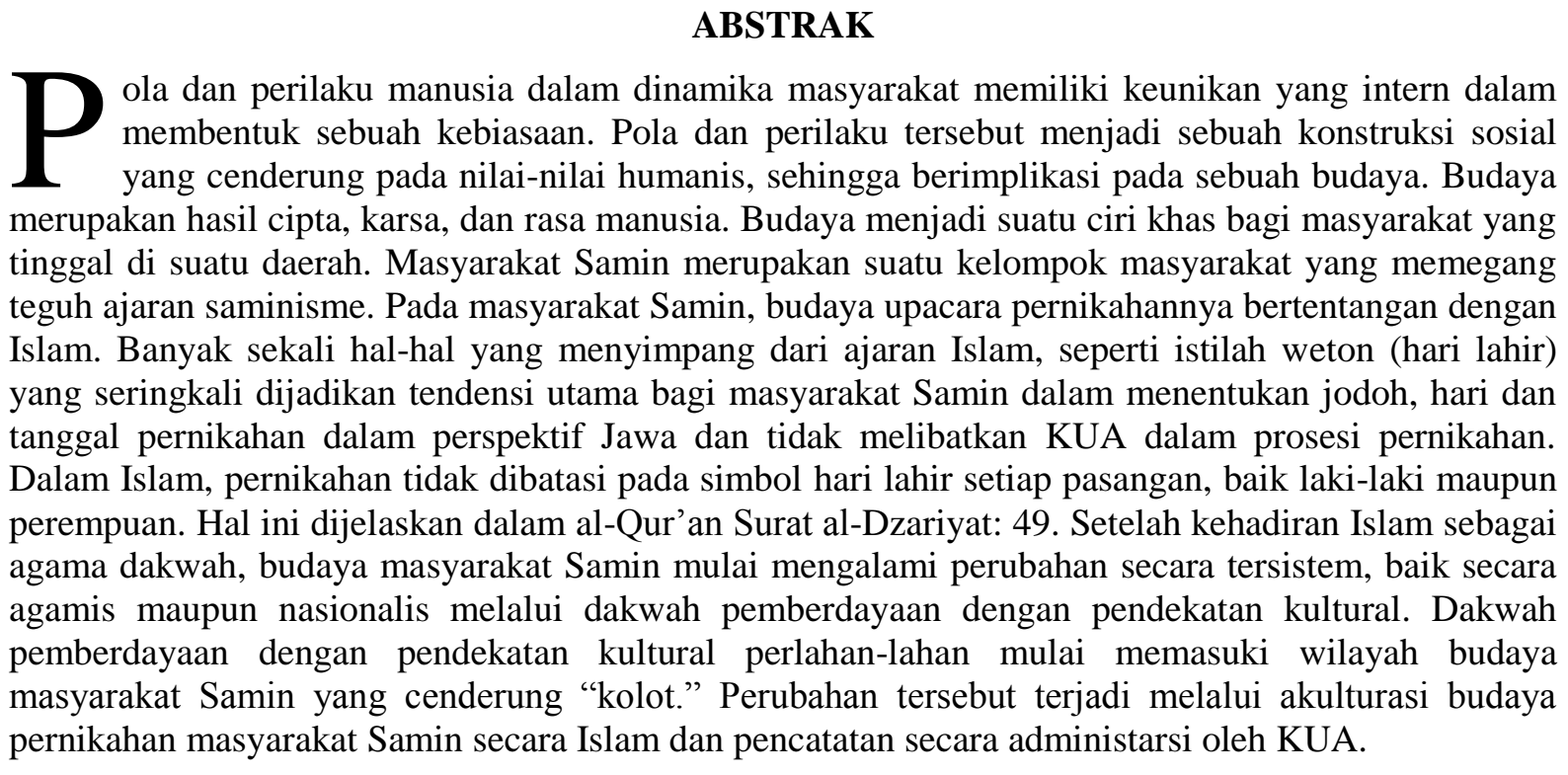

Kata kunci :dakwah kultural, upacara pernikahan, masyarakat Samin.

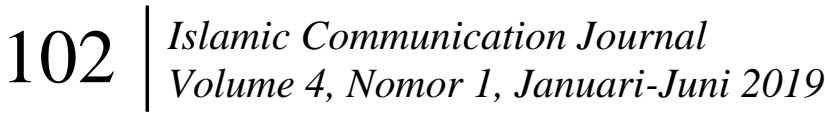




\section{PENDAHULUAN}

Indonesia merupakan negara yang kaya akan budaya yang beraneka ragam. Budaya Indonesia yang beragam ini dihasilkan oleh berbagai macam suku yang ada di Indonesia. Perbedaan tersebut tentu masih diikat dalam tali persatuan yaitu Bangsa Indonesia (Trianingsih, dkk, 2017 : 45). Dalam dinamika kebudayaan tersebut terdapat elemen-elemen yang sangat signifikan. Elemen-elemen tersebut didesain dalam adat-istiadat yang tercakup dalam sistem nilai, budaya, dan norma. Adat istiadat yang diaplikasikan dalam kehidupan sehari-hari menjadi sebuah kebiasan yang berimplikasi pada sebuah tatanan hukum adat (Sarjono, 1998 : 614). Dalam konteks ini, hukum adat istiadat tentu ada dan sangat penting bagi suatu masyarakat.

Adat istiadat juga menjadi salah satu bagian terpenting dari sebuah upacara pernikahan di Indonesia. Sebab, pernikahan menjadi salah satu bagian terpenting dalam menjalani dinamika kehidupan. Selain untuk membentuk keluarga, pada kodratnya pernikahan juga sebagai sarana untuk memenuhi kebutuhan biologis manusia. Pada dasarnya pernikahan tidak hanya mempersoalkan masalah hubungan manusia dengan manusia. Akan tetapi, pernikahan juga mempersoalkan tentang masalah agama sehingga setiap agama memiliki aturan tersendiri dalam hal pernikahan (Taufiq, 2006: 54).

Peraturan pemerintah dalam Pasal 1 Undang-Undang Pernikahan Nomor 1 Tahun 1974 menjelaskan bahwa pernikahan dilakukan untuk membentuk keluarga yang bahagia dan kekal berdasarkan ketuhanan Yang Maha Esa (KEMENAG, 2012: 2). Mengacu dari Undang-Undang Pernikahan tersebut, maka muncul asas-asas prinsipil salah satunya yaitu pernikahan menganut prinsip bahwa calon suami istri harus telah siap jiwa dan raganya untuk dapat melangsungkan pernikahan, agar dapat mewujudkan tujuan pernikahan secara baik tanpa harus berpikir untuk bercerai dan mendapat keturunan yang baik dan sehat (Rofiq, 2010: 7).

Penjelasan mengenai Undang-Undang Pernikahan yang memunculkan asas prinsipil menjadi bagian dari budaya masyarakat Samin yang semakin unik. Masyarkat Samin (Turner, 1966: 19) merupakan masyarakat yang hidup di pedesaan dan pertanian menjadi salah satu sumber pokok kehidupan di desa. Adat istiadat upacara pernikahan samin lebih cenderung menganut agama Adam. Masyakarat Samin menyebut pernikahan dengan bebrayan, serta menyertakan pasangannya dengan istilah rerukunan. Pernikahan yang dilakukan oleh masyarakat Samin tidak mengikuti aturan dan ketentuan yang ditetapkan oleh pemerintah seperti Undang-Undang Pernikahan No. 1 Tahun 1974 dan Kompilasi Hukum Islam, padahal mereka merupakan bagian dari warga Indonesia dan mengaku sebagai muslim.

Pernikahan masyarakat Samin (Taufiq, 2006: 54) memiliki beberapa tahapan, seperti nyumuk (kedatangan orang tua calon pengantin putra ke calon pengantin putri untuk menanyakan keberadaan calon menantu), ngendek, nyuwito, pasaksen, dan lain sebagainya. Upacara pernikahan masyarakat Samin merupakan salah satu prosesi adat yang diwariskan oleh nenek moyang. Ketentuan-ketentuan yang sudah ditetapkan oleh masyarakat Samin tentu sudah diyakini dan mengandung sakralitas atau magis.

Islamic Communication Journal Volume 4, Nomor 1, Januari-Juni 2019 103 


\section{Ali Damsuki}

Dalam perspektif Islam, budaya atau adat tersebut tentu tidak menjadi sebuah kebiasaan sehingga datangnya agama Islam sebagai agama dakwah tentu menjadi hal yang kurang diperhatikan oleh masyarakat Samin sendiri. Sebab, masyarakat Samin memiliki sifat individualistik yang tinggi. Dalam Islam, entitas dakwah merupakan proses mengajak dari hal yang buruk ke arah yang benar (amar ma'ruf nahi munkar). Kondisi tersebut tentu sangat 'diamini' oleh kaum muslimin, bahwa tanggungjawab tersebut merupakan bagian dari kita sebagai umat Islam terbaik. Hal tersebut diperkuat dengan ayat Al-Qur'an surat Ali Imron : 110

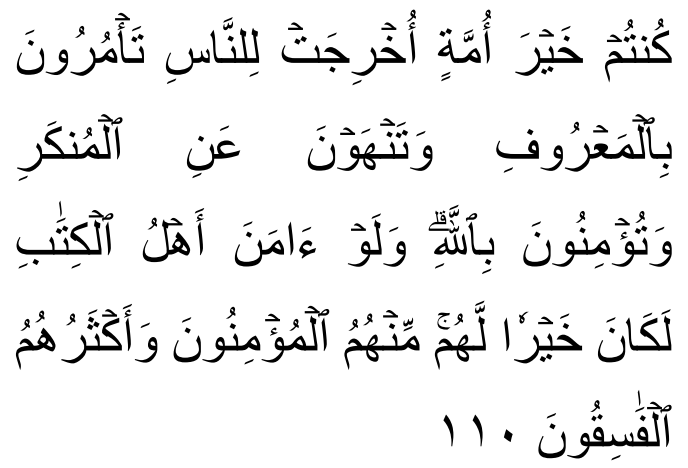

"Kamu adalah umat yang terbaik yang dilahirkan untuk manusia, menyuruh kepada yang ma'ruf, dan mencegah dari yang munkar, dan beriman kepada Allah. Sekiranya Ahli Kitab beriman, tentulah itu lebih baik bagi mereka, di antara mereka ada yang beriman, dan kebanyakan mereka adalah orangorang yang fasik" (Qs. Ali-Imron : 110) (DepAg, 2015 : 195).

Dakwah menjadi peran sentral bagi kaum muslimin dalam menjalankan kewajiban. Peran tersebut dilakukan oleh kita sebagai da'i dalam mengajarkan dan mengamalkan ajaran ke-Islaman secara kaffah. Dalam konteks kebudayaan, dakwah memiliki ciri khas dan metode yang unik. Keunikan tersebut merupakan bagian dari tantangan para da'i dalam menjalankan misi suci yang harus dilakukan. Apabila kita melihat para pemuka agama, seperti Nabi Muhammad Saw, para sahabat, ulama', dan para Walisongo, tampaknya mereka mencoba mengaktualiasikan dakwah dengan pendekatan dakwah kultural melalui akulturasi budaya..

Pendekatan dakwah kultural merupakan metode dakwah melalui akulturasi budaya yang digunakan dan sesuai dengan latar belakang uniknya budaya yang ada. Kebudayaan animisme dan dinamisme pada zaman dahulu menjadi hal yang sangat 'diagungkan.' Berbagai macam bentuk benda yang mengandung sakralitas atau magis menjadi kekuatan dalam membentuk konstruksi paradigma masyarakat. Kedatangan Islam yang dibawa oleh para ulama Islam tidaklah menghilangkan budaya dari masyarakat setempat. Kondisi tersebut tentu merupakan proses pendekatan dakwah kultural yang dilakukan melalui akulturasi budaya yang dilakukan dengan memahami para mad'u atau masyarakatnya dan budaya yang ada.

Budaya masyarakat Samin merupakan budaya yang memiliki ciri khas yang unik. Keunikasn itu terlihat dari kondisi masyarakat yang masih memegang budaya warisan dari nenek moyang mereka. Stigma masyarakat yang memandang bahwa masyarakat Samin memiliki jiwa "kolot" (memegang teguh budaya) terisolasi dalam sebuah komunitas kecil dan terlihat aneh dalam dinamika masyarakat secara umum. Hal inilah yang selalu menjadi hal kontroversial dan unik serta layak untuk dikaji, khususnya dalam konteks budaya pernikahan masyarakat Samin. 
Tulisan ini termasuk kajian literatur jenis kualitatif dengan pendekatan deskriptif-analitis dan berbasis pada kajian kepustakaan. Artikel ini merupakan sebuah refleksi yang ingin mengungkapkan pentingnya pendekatan dakwah kultural dalam upacara penikahan masyarakat Samin. Oleh sebab itu, perlunya sebuah proses islamisasi dengan pendekatan dakwah kultural melalui akultutasi budaya. Akulturasi budaya menjadi salah satu pendekatan dakwah yang dilakukan oleh para da'i pendahulu pada masyarakat Samin. Akulturasi budaya tersebut memiliki tujuan untuk memasukkan nilainilai Islami pada budaya upacara pernikahan masyarakat Samin yang cenderung kurang sesuai dengan ajaran Islam dan aturan pemerintah atau negara.

\section{PEMBAHASAN}

\section{Pendekatan Dakwah Kultural}

Bungo (2014: 209) menjelaskan bahwa pendekatan dakwah kultural merupakan pendekatan yang yang berusaha meninjau kembali kaitan doktrinal formal antara Islam dan politik atau Islam dan negara. Pendekatan dakwah kultural mulai menjadi sebuah metode yang digunakan untuk mengatasi problematika masyarakat yang ada. Seperti halnya hubungan antara Islam dan politik atau Islam dan negara termasuk wilayah pemikiran ijtihadiyah, yang tidak menjadi persoalan bagi umat Islam ketika sistem kekhalifahan masih bertahan di dunia Islam. Setelah hancur sistem kekhalifahan di Turki, dunia Islam di hadapkan pada sistem politik Barat.

Dalam kaitan itu, hubungan Islam dan negara menjadi bagian dari persoalan serius. Ada yang berpendapat bahwa negara-negara yang berdiri di dunia Islam itu identik dengan sistem kekhalifahan pada masa klasik. Sistem kekhalifahan itu sendiri dianggap sebagai bagian dari ajaran Islam yang diwariskan oleh Rasulullah. Oleh karena itu, ada pemikiran bahwa antara Islam dan negara terjalin hubungan doktrinal secara formal. Oleh sebab itu, dakwah kultural menjadi pendekatan yang sesuai dengan kondisi yang ada.

Menurut Sulthon (2003: 26), dakwah kultural merupakan aktivitas dakwah yang menekankan pendekatan Islam kultural. Melalui pemahaman Islam yang kontekstual, berbagai kebudayaan yang ada di masyarakat dapat adaptasikan dengan nilai-nilai Islam. Islam kultural adalah proses pendekatan dakwah melalui akulturasi budaya. Akulturasi budaya ini sebagai upaya penerapan nilai-nilai ajaran Islam dengan mempertimbangkan unsurunsur budaya lokal yang ada.

\section{Akulturasi Budaya}

Kata budaya menurut Jaunad (2013: 2) ialah pikiran, akal budi, adat istiadat dan sesuatu yang menjadi kebiasaan. Sedangkan kata kebudayaan ialah hasil kegiatan dan penciptaan batin (akal budi) manusia. Seperti kepercayaan, kesenian dan adat istiadat atau keseluruhan pengetahuan manusia sebagai makhluk sosial yang digunakan untuk memahami lingkungan serta pengalamannya dan yang menjadi pedoman tingkah lakunya. Pendapat lain mengemukakan bahwa kebudayaan adalah semua hasil karya, rasa dan cipta masyarakat, yang menghasilkan teknologi dan kebudayaan kebendaan yang diperlukan oleh manusia untuk menguasai alam sekitarnya, agar kekuatan serta hasilnya dapat diabadikan oleh masyarakat.

\section{Islamic Communication Journal Volume 4, Nomor 1, Januari-Juni 2019 $\mid 105$}




\section{Ali Damsuki}

Dengan demikian, kebudayaan pada dasarnya adalah hasil cipta, rasa dan karsa manusia.

Akulturasi menurut Redfield Linton dan Herskovis (1936), "Acculturation comprehends these phenomena which result when group of individuals having different cultures come into continous firsthand contact, with subsequent change in the original culture pattern of either or both groups". Akulturasi dapat dipahami sebagai fenomena yang terjadi ketika sekelompok individu yang memiliki budaya berbeda melakukan kontak langsung secara terus-menerus dan mengalami perubahan pola budaya pada kedua kelompok tersebut (Poerwanto, 2010 : 105).

Akulturasi merupakan suatu proses sosial yang timbul bila suatu kelompok manusia yang memiliki suatu kebudayaan tertentu berhubungan dengan unsur-unsur dan suatu kebudayaan asing sehingga unsur-unsur kebudayaan asing tersebut lambat laun diterima dan diolah ke dalam kebudayaan sendiri tanpa menyebabkan hilangnya kebudayaan asli. Berdasarkan hak tersebut kebudayaan memiliki dua bagian, yakni bagian yang sukar berubah/ terpengaruh (covert culture) dan kebudayaan yang mudah berubah/ terpengaruh (overt culture). Covert culture meliputi sistem nilai-nilai budaya, keyakinan-keyakinan keagamaan yang dianggap keramat, adat yang sudah lama melekat dalam kehiduan masyarakat dan adat yang memiliki fungsi yang terjaring luas dalam masyarakat. Sementara overt culture meliputi kebudayaan fisik, ilmu pengetahuan, tatacara, gaya hidup, dan rekreasi (Ayuningrum, 2017: 130).

Proses akulturasi dimulai ketika sebuah kebudayaan bertemu awal dengan kebudayaan baru. Kemudian unsur-unsur dari masing-masing kebudayaan yang berbeda saling bercampur satu sama lain sebagai akibat dari pergaulan atau interaksi yang intensif dalam waktu yang lama, namun tidak menyebabkan munculnya budaya baru. Dua budaya yang berbeda membentuk sebuah kebudayaan yang baru dengan tidak menghilangkan ciri masingmasing kebudayaan (Ayuningrum, 2017: 131).

Dalam peristiwa kontak kebudayaan atau akulturasi budaya ini seringkali terjadi perubahan dan perkembangan kebudayaan pada suatu masyarakat. Proses ini tentu dapat menimbulkan sejumlah masalah, baik yang berpengaruh positif maupun negatif. Adapun masalah-masalah tersebut di antaranya menurut (Kodiran : 1998, 90) :

a. Adisi (addition) ialah penambahan unsur-unsur kebudayaan yang lama oleh kompleksnya unsur-unsur kebudayaan yang baru sehingga timbul perubahan struktural atau tidak sama sekali;

b. Sinkretisme ialah perpaduan antara unsur-unsur kebudayaan yang lama dengan kompleksnya unsur-unsur kebudayaan yang baru dengan tidak meninggalkan jati diri masing-masing dan membentuk sistem kebudayaan yang baru;

c. Substitusi (substitution) ialah unsurunsur kebudayaan yang ada atau yang terdahulu diganti oleh kompleks unsurunsur budaya yang baru, terutama yang dapat memenuhi fungsinya. Dalam hal ini, kemungkinan akan terjadi perubahan struktural sangatlah kecil;

d. Dekulturasi (deculturation) ialah tumbuhnya unsur-unsur kebudayaan yang baru untuk memenuhi berbagai kebutuhan baru yang timbul karena perubahan situasi; 
e. Rejeksi (rejektion) ialah penolakan unsur-unsur perubahan yang terjadi secara cepat sehingga sejumlah besar orang tidak dapat menerimanya. Hal ini dapat menimbulkan penolakan secara otomatis, bahkan hingga pemberontakan atau gerakan kebangkitan.

Dalam konteks kebudayaan pernikahan masyarakat Samin, rejeksi (rejektion) merupakan faktor yang sesuai dengan awal mula munculnya kebudayaan masyarakat Samin yang lahir dari nenek moyang. Kebudayaan nennek moyang yang kaku tersebut tentu tidak dengan mudah dapat berubah dengan cepat Hadirnya Islam sebagai agama dakwah, sinkretisme sebagai faktor akulturasi buadaya dapat berproses secara perlahan tanpa meninggalkan budaya yang ada. Kemudian faktor-faktor lainnnya sebagai pendukung dakwah dalam proses akulturasi budaya yang berjalan melalui pendekatan kultural maupun struktural dalam masyarakat Samin tersebut.

\section{Masyarakat Samin}

Masyarakat Samin (Syah, 2016: 3) merupakan bagian terkecil dari berbagai macam ras tersebut. Bagi kalangan aktivis pluralis, masyarakat Samin lebih dikenal dengan sedulur sikep. Samin memiliki arti sama, kesamaan, sama saja, setara atau senasib sepenanggungan. Arti-arti tersebut melahirkan makna kehidupan yang tidak memiliki perbedaan di mata alam dan Tuhan. Tidak ada yang bisa membedakan antara satu individu dengan individu lainnya, kecuali kebaikan serta nilai ketuhanan dalam diri atau ketakwaan.

Masyarakat Samin memandang alam sebagai tempat tinggal. Apa yang tumbuh dan bersumber dari alam adalah milik bersama yang harus dijaga dan dihormati sehingga banyak nilai kearifan yang dipraktikan oleh masyarakat Samin. Mayoritas masyarakat Samin adalah petani sehingga petani adalah pekerjaan prestisius bagi anak-anak muda di masyarakat Samin (Syah : 2016, 4). Masyarakat Samin yang masih tersebar di daerah Kab. Blora, Pati, dan sekitarnya memiliki pandangan kaku dalam konteks masyarakat era modern. Hal tersebut tentu melihat karakteristik masyarakat Samin yang non-doktiner, individualisme kelompok yang kuat, kaku, dan lain sebagainya.

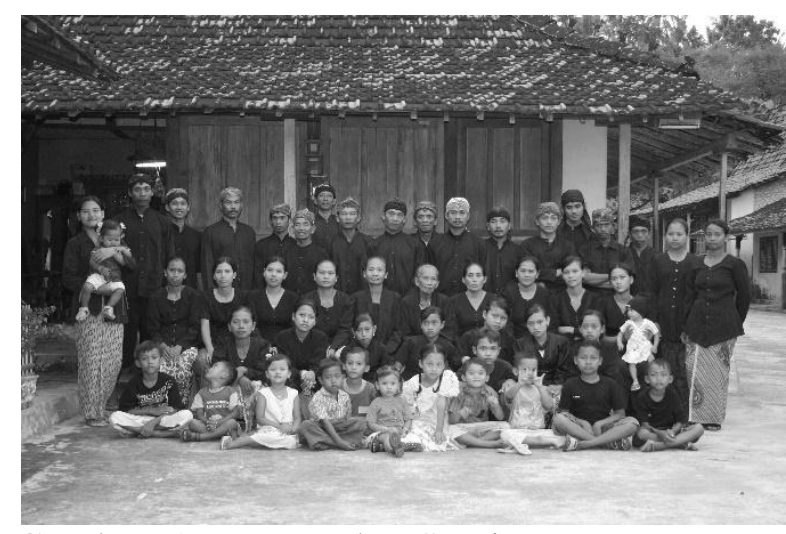

Gambar. 1. Masyarakat Samin

Sumber:Louisalx.blogspot.com,(Alexander, 2014)

Foto masyarakat Samin tersebut menggambarkan bahwa tingkat kekerabatan yang kuat, saling mendukung antara satu dengan yang lain dengan keberagaman yang sama. Inilah yang menjadi ciri khas yang unik untuk dikaji secara mendalam. Sarjono(1998: 614) mendefinisikan kata Samin berasal dari kata sami-sami amin (Jawa) atau sama-sam bermufakat dalam melakukan sesuatu untuk mencapai kesejahteraan, yang menunjukkan bahwa manusia sama derajatnya. Pandangan yang menghargai 


\section{Ali Damsuki}

hak-hak manusia ini merupakan pandangan yang dijunjung oleh pengikut Samin. Mereka tidak merasa derajatnya lebih rendah daripada priyayi Jawa dan orangorang Belanda pada zaman kolonial pada saat munculnya ajaran ini. Nama Samin pada ajaran Samin juga diambil dari nama pendirinya, Samin Surosentiko yang lahir pada tahun 1859 di desa Ploso Kediren Kecamatan Randublatung Kabupaten Blora.

Pada mulanya merupakan usaha perlawanan terhadap pemerintah kolonial Belanda. Data sejarah menunjukkan bahwa perlawanan tersebut dipimpin oleh orangorang dari golongan tertentu yang kemudian menjadi cikal-bakal komunitas Samin. Perlawanan dipimpin oleh kalangan bangsawan, yaitu Raden Kohar yang kemudian berganti nama Samin Surosentiko. Samin Surosentiko merupakan keturunan Kusumaningayu. Ayahnya bernama Raden Surowijoyo yang dikenal dengan Samin Sepuh yang bekerja sebagai perampok untuk kepentingan orang miskin. Raden Kohar berganti nama Samin, karena Samin lebih merakyat. Pada saat umur 31 tahun (1890) ia mulai menyebarkan ajarannya. Pada tahun 1970, orang Samin merencanakan perlawanan terhadap pemerintah Belanda. Rencana itu kemudian terdengar oleh pemerintah Belanda dan direspon dengan penangkapan sejumlah orang Samin(Sarjono, 1998: 614).

Munculnya gerakan perlawanan Samin disebabkan oleh kesewenang-wenangan penjajah Belanda yang merampas tanah rakyat untuk perluasan areal hutan jati. Perlawanan Samin terhadap pemerintah Belanda tidak dilakukan secara fisik, melainkan dengan cara penentangan terhadap segala peraturan yang telah ditetapkan oleh pemerintah Belanda dan pembangkangan atas kewajiban yang harus dilakukan rakyat, seperti tidak mau membayar pajak dan tidak mau menyerahkan hasil panen kepada pemerintah Belanda. Terbawa dengan sikapnya yang menentang tersebut mereka membuat tatanan, adat istiadat, dan kebiasaan-kebiasaan tersendiri.

Menurut Sarjono (1998: 614), Saminisme dalam masyarakat Samin adalah fenomena yang unik dan perlu untuk dikaji. Keunikannya antara lain terletak pada kemunculan samnisme pertama kali, yakni sebagai moral yang dilakukan oleh Samin Surosentiko melawan penjajah Belanda. Pada perkembangannya, aksi moral Samin Surosentiko menjadi gerakan moral, kemudian berkembang menjadi gerakan kultural dengan bergulirnya ideologi Saminisme. Keunikan yang lain, Samin selalu diidentikkan dengan keluguan dan kebodohan, tapi dengan kebodohannya terdapat kecerdikan. Disebut lugu dan bodoh karena mereka dapat berkomunikasi secara lugas, mereka seolah-olah tidak mengenal bahasa politik. Kecerdikannya, mereka mampu memperdaya pemerintah Belanda dengan bahasa yang lugas (Sarjono, 1998: 615).

Sedangkan pada masyarakat Samin di Kabupaten Blora terdapat dua karakterisrtik Samin, yaitu Samin Muda dan Samin Tua. Samin Muda memiliki karakteristik yang ekstrovert (mudah bergaul dan terbuka). Samin Muda memiliki sifat gotong royong yang tinggi, solidaritas yang kuat, dan memiliki tungkat persaudaraan yang tinggi. Sedangkan golongan masyarakat Samin Tua cenderung non-doktiner, kolot, terpaku pada budaya nenek moyang, tidak berpendidikan secara formal sehingga juga memiliki pemikiran yang kuno. 
Dalam konteks lain juga, Samin terbagi atas (1) Samin Sangkak, jika berinteraksi dengan pihak lain, menjawab dengan remeh temeh. Samin Sangkak lebih suka menutupi kegiatannya jika ditanya oleh pihak lain. Hal ini terbawa karakter Samin masa lalu agar tak teridentifikasi Belanda. (2) Samin Ampeng-ampeng; mengaku Samin, perilakunya tak sebagaimana ajaran

Samin atau jika berbicara seperti Samin sangkak perilakunya tak Samin sejati. (3) Samin samiroto; mengaku Samin juga mengikuti adat non-Samin, dan (4) Samin Sejati atau dlejet/ dledek; berpegang prinsip Samin secara utuh.

Mata pencaharian masyarakat Samin mayoritas adalah petani, mereka menghindari pekerjaan yang berbau peerdagangan yang mengambil dari produsen atau dalam istilah Jawa yaitu dagang kulak karena perdagangan bukan ajaran dari moyang mereka. Masyarakat Samin juga beranggapan bahwa perdagangan bukan ajaran dari nenek moyang mereka. Masyarakat Samin juga beranggapan bahwa berdagang memiliki potensi untuk berbohong, sedangkan mereka tidak suka dengan kebohongan. Namun, masyarakat Samin yang sudah Islam tidak terlalu kaku dengan ajaran nenek moyang yang pernah ia dapatkan sewaktu masih Samin. Masyarakat Samin yang sudah Islam mulai terbuka dengan kondisi sosial yang ada, ada yang mulai berdagang dan juga memuka usaha seperti bengkel, toko material, warung, penggilingan padi dan lain sebagainya (Trianingsih, dkk, 2017: 52).

Salah satu contoh di kahidupan masyarakat Samin di Desa Baturejo Kabupaten Pati yang tingkat pendidikannya tidak terlalu tinggi. Hanya beberapa saja yang lulus dari Perguruan Tinggi. Bahkan penduduk yang tidak bersekolah tingkatnya cukup tinggi di desa tersebut. Hal ini terjadi karena masyarkat Samin tidak ingin menyekolahkan anak-anaknya dengan alasan sekolah bukan merupakan ajaran dari nenek moyang mereka. Kalaupun ada hanya segelintir saja yang bersekolah, itupun belum tentu lulus Sekolah Dasar.

Tabel I Jumlah penduduk Berdasarkan Pendidikan

\begin{tabular}{|c|l|c|}
\hline No & \multicolumn{1}{|c|}{ Tingkat Pendidikan } & Jumlah \\
\hline 1 & Tamat Akademik/Perguruan Tinggi & 35 \\
\hline 2 & Tamatan SLTA & 190 \\
\hline 3 & Tamatan SLTP & 452 \\
\hline 4 & Tamatan SD & 894 \\
\hline 5 & Tidak Tamat SD & 99 \\
\hline 6 & Belum Tamat SD & 223 \\
\hline 7 & Tidak Sekolah & $\mathbf{2 3 1 4}$ \\
\hline & Jumlah & 421 \\
\hline
\end{tabular}

Sumber : (Trianingsih, dkk, 2017: 53).

Angka pada kolom tidak bersekolah cukup tinggi, kenyataan tersebut didukung oleh jumlah anak-anak Masyarakat Samin yang tidak bersekolah. Alasan Masyarakat Samin tidak menyekolahkan anak-anak mereka adalah tidak mau apabila anak turunan mereka sekolah dididik untuk menjadi orang yang pintar kemudian pintar mengelabuhi orang lain, karena kebanyakan orang yang korupsi adalah karena mereka pintar. Namun anak-anak keturunan hasil pernikahan silang antara Samin dan Islam sudah mulai bersekolah selayaknya anakanak pada umumnya (Trianingsih, dkk, 2017: 54). 


\section{Ali Damsuki}

\section{Upacara Pernikahan dalam Masyarakat}

\section{Samin}

Kebudayaan atau adat istiadat merupakan hal yang sering ada dalam lingkungan sekitar kita sehingga sebuah adat atau kebudayaan seringkali berimplikasi pada sebuah nilai dan tata hukum yang diatur dalam komunitas tersebut. Menurut (Laksono, 2013: 217) kebudayaan atau adat istiadat merupakan suatu tatanan prilaku masyarakat yang seringkali dilakukan dan dianggap sakral sehingga membentuk suatu sistem hukum dalam taraf sederhana.

Menurut (Rosyid, 2015: 237) kebudayaan masyarakat Samin memiliki keberagaman yang unik. Hal tersebut dapat dilihat melalui gaya hidup yang sangat jauh dari masyarakat pada umumnya. Kebudayaan pernikahan dalam kehidupan masyarakat Samin tidak melibatkan pihak KUA. KUA tidak menjadi hal fundamental dalam prosesi sakral tersebut.

Karakteristik masyarakat Samin yang non_doktriner menjadi hal yang sulit untuk mengubah tradisi yang selama ini dipegang teguh sejak nenek moyang. Salah satunya ialah upacara pernikahan. Budaya masyarakat Samin dalam upacara pernikahan, ada budaya pasuwitan. Pasuwitan merupakan budaya dalam tahapan pernikahan yang dijadikan sebuah legalitas dalam sebuah budaya tersebut. Prosesi pasuwitan berlangsung dengan pengantin putra hidup bersama keluarga pengantin putri dalam satu rumah untuk ngawulo kepada orang tua pengantin dengan membantu melaksanakan pekerjaan yang dilaksanakan mertuanya. Rentang waktu pasuwitan tidak dibatasi waktu dan ditentukan oleh kedua pengantin jika sudah mengalami kecocokan.

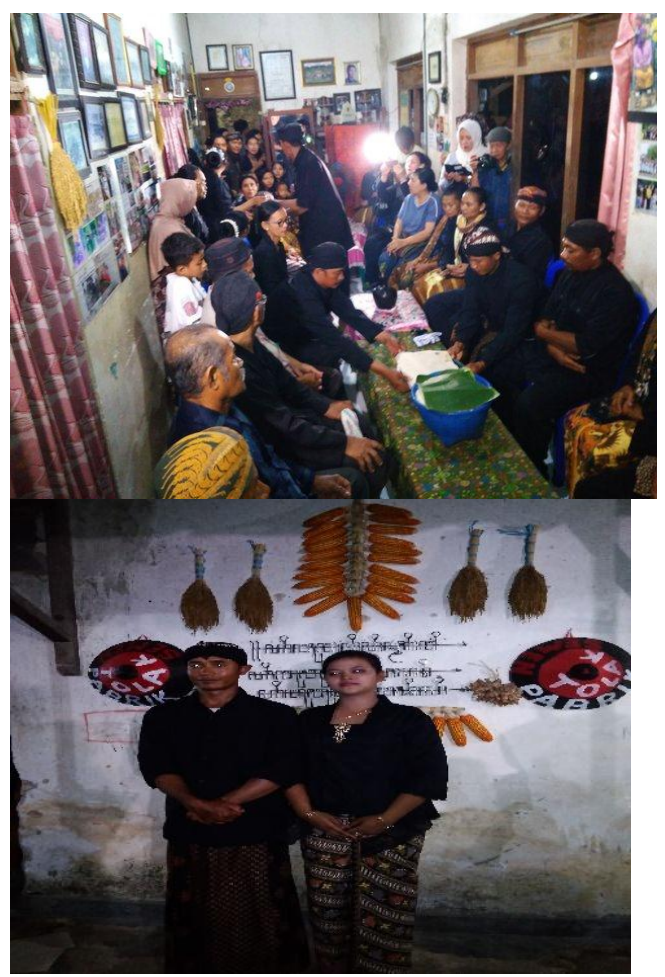

Gambar. 2. Pasuwitan

Sumber : Steemit.com, (Bambangsoe, 2018)

Proses pasuwitan ini merupakan suatu budaya yang langka (di depan kamera). Pada foto tersebut terlihat hanya ada dua keluarga pasangan calon suami istri yang datang ke rumah salah satu calon mempelai tanpa membawa barang antaran, mas kawin, ataupun hidangan. Kecocokan itu terlihat dengan pengantin putra berhubungan badan dengan pengantin putri. Setelah melakukan hubungan intim barulah melakukan paseksen dengan mengundang tetangga sebagai saksi bahwa sepasang pengantin putra putri tersebut telah sah sebagai pasangan suami istri. Pasuwitan merupakan sebuah tradisi yang dijadikan sebagai legalitas perkawinan oleh Suku Samin. Meskipun begitu, tradisi pasuwitan yang ada di masyarakat Suku Samin ini memiliki beberapa alasan di antaranya budaya ini merupakan budaya yang sudah turun temurun dan baik sehingga 
pernikahan masyarakat Samin dianjurkan dengan budaya pasuwitan agar pernikahan mereka sah (Taufiq, 2006: 65).

Prosesi pasuwitan sebagai budaya legalitas dalam pernikahan masyarakat Samin tentu mengakibatkan polemik di Indonesia. Sebab, Indonesia sebagai negara hukum memiliki aturan dalam proses pencatatan warga yang sudah menikah. Namun, tradisi masyarakat Samin tidak terlalu mematuhi aturan yang sudah ditetapkan oleh negara. Prinsip-prinsip pernikahan yang sudah jelas dalam undangundang No 1 tahun 1974, bahwa pernikahan menjadi sah apabila dilakukan menurut hukum masing-masing agamanya dan kepercayaanya itu, dan di samping itu tiap-tiap pernikahan harus dicatat menurut peraturan perundang-undangan yang berlaku (KEMENAG, 2013: 29-31). Dalam undang-undang tersebut sudah jelas bahwa tiap-tiap pernikahan itu harus dicatatkan, sedangkan jika dilihat dari apa yang terjadi di masyarakat Samin ini tampak bertolak belakang. Artinya kebiasaan yang ada di masyarakat Samin tidak sesuai dengan peraturan yang ada.

Dalam prosesi upacara pernikahan, banyak hal-hal yang menjadi sebuah aturan khusus bagi masyarakat Samin sendiri selain pasuwitan. Penelitian Rosyid (1998: 237) mencatat lima tahapan perkawinan masyarakat Samin:

1. Nyumu' merupakan istilah yang digunakan dalam prosesi kedatangan (calon) pengantin putra ke keluarga (calon) pengantin putri untuk menanyakan keberadaan calon menantu, sudah memiliki suami atau masih gadis (legan).

2. Ngendek merupakan istilah pernyataan calon dari keluarga penganten putri untuk menindaklanjuti prosesi nyumu'.
Pelaksanaan ngendek diawali dengan pernyataan calon pengantin kepada bapak ibunya, dengan menyatakan keinginan mempersunting seorang putrinya. Dalam prosesi ngendek calon pengantin putra tidak ikut (menghadiri) di rumah calon pengantin putri.

3. Nyuwito-ngawulo merupakan istilah hari dilangsungkannya pernikahan niat pengantin putra untuk meneruskan keturunan (wiji sejati, titine anak adam). Dalam proses ini pengantin putra hidup bersama keluarga pengantin putri dalam satu rumah (ngawulo) atau pengantin putri hidup bersama keluarga pengantin putra, berdasarkan kesepakatan keluarga kedua belah pihak. Pada proses nyuwito pada dasarnya untuk mencari proses kecocokan calon pengantin dengan hidup bersama di tempat calon mertuanya. Waktu yang dibutuhkan dalam proses nyuwito tidak ditentukan.

4. Paseken merupakan istilah forum ungkapan penganten putra di hadapan orang tua (mertua) yang dihadiri penganten putri, keluarga, dan tamu undangan baik dari warga Samin maupun non Samin. Acara tersebut setelah kedua calon penganten melangsungkan hubungan suami-istri (kumpul) dalam proses nyuwito tersebut.

5. Proses paseksen ini merupakan proses "resepsi" pernikahan atau "walimatul 'ursy" dalam masyarakat non Samin (atau umat Islam). Tingkep setelah pengantin hamil dalam usia kandungan tujuh bulan, diadakan prosesi selamatan bayi dalam kandungan yang disebut brokohan (selamatan).

Masyarakat Samin merupakan salah satu masyarakat yang menganut paham monogamy sehingga dalam sebuah pernikahan tidak mengenal istilah 


\section{Ali Damsuki}

perceraian kecuali "salin sandang" atau meninggal dunia. Hal ini tentu sesuai dengan paradigma masyarakat Samin yang mengontekstualisasikan perilaku dengan mengaitkan sisi moral. Seperti halnya adanya suatu masalah seperti pertengkaran dan perselisihan dalam keluarga. Kondisi tersebut sangat melanggar ketentuan dalam masyarakat Samin dan sangat dilarang.

Selain itu, (Laksanto, 2005:

masyarakat Samin memiliki sifat selalu menjaga kelompoknya. Hal ini berimplikasi pada sebuah pernikahan yang notabene hanya menghendaki kelompoknya sendiri dalam mencari jodoh. Prosesi upacara pernikahan yang dilakukan oleh masyarakat Samin hanya cukup dihadiri oleh kerabat dan direstui oleh sesepuh Samin tersebut tanpa melibatkan pihak keagamaan seperti KUA dan Departemen Agama sebagai legalitas (Mukoyimah, 2015: 63).

\section{Pendekatan Dakwah Kultural dalam}

\section{Upacara Pernikahan Masyarakat Samin}

Kehadiran Islam menurut Junaid (2013: 2 ) di Indonesia yang dibawa oleh para mubaligh memiliki tugas ganda, karena di samping membawa misi Islamisasi, mereka juga sebagai pedagang Islami, dengan menggunakan metode dakwah secara persuasif dan adaptif (bi almau'idzatil al hasanah) dengan tradisi atau budaya Indonesia sehingga terjadi akulturasi timbal balik. Penyebaran Islam secara damai dengan tradisi dan budaya masyarakat setempat memberi pengaruh terhadap percepatan proses Islamisasi di Indonesia.

Budaya lokal memang tidak dapat mengalami akulturasi secara menyeluruh. Akan tetapi, proses akulturasi tersebut dapat mengalami perubahan budaya di beberapa dimensi budaya saja. Sebab. budaya lokal tersebut juga terbatas pada garis wilayah yang didiami oleh setiap kelompok dalam masyarakat. Seperti halnya budaya upacara pernikahan masyarakat Samin yang cenderung lebih menggunakan sistem kekeluargaan dan bersifat tertutup. Hakikat metode merupakan cara atau alat yang digunakan untuk menyelesaikan persoalan yang ada dalam dinamika masyarakat. Melihat kultur masyarakat Samin yang "mengamini" sebuah kebudayaan yang tidak dapat ditinggalkan dalam dinamika masyarakat, maka diperlukan metode dakwah yang efektif dan mampu mengubah paradigma dan perilaku yang dianggap "aneh" oleh sebagian besar orang secara umum, terutama dalam konteks ke-Islaman.

Karakteristik masyarakat Samin yang sangat taat pada pemimpinnya, tentu hal ini menjadi sebuah peluang atau salah satu strategi dakwah melalui pemimpinnya terlebih dahulu. Metode dakwah yang digunakan dalam menghadapi masyarakat Samin ialah menggunakan metode dakwah bil hal dengan pendekatan budaya. Hal ini tentunya diaplikasikan dengan melihat kondisi mad'u yang cenderung tradisionalis dan non-doktriner sehingga perlu upaya keras terutama dalam hal prilaku intens dalam mendampingi masyarakat samin, terutama dalam konteks kebudayaan(Rosyid : 1998, 239).

Proses akulturasi budaya yang dilakukan oleh para da'i pendahulu terhadap masyarakat Samin menggunakan pendekatan persuasif dengan berpedoman pada al-Qur'an dan al-Hadist. Hukum pernikahan itu sendiri tertera dalam alQur'an Surat An-Nur 24: 23 :

"Dan kawinkanlah orang-orang yang sendirian diantara kamu, dan orang- 
orang yang layak (berkawin) dari hamba-hamba sahayamu yang lelaki dan hamba-hamba sahayamu yang perempuan, jika mereka miskin dan memampukan mereka dengan karunianya dan Allah maha luas (pemberian-Nya) lagi maha mengetahui." (Surat An-Nur $24: 23$ ) (Departemen Agama, 2015).

Dari adanya sumber hukum di atas jelas bahwa Rasullulah SAW memerintahkan kepada para pemuda yang sudah mampu dan sanggup baik secara materi, jasmani maupun rohani untuk segera menikah (Taufiq, 2006: 70). Namun dalam prosesi adat kebudayaan pasuwitan masyarakat Samin tentu tidak terlalu mengutamakan syarat-syarat nikah yang syarat dan rukun pernikahan itu di antaranya:

a. Adanya calon suami dan isteri yang akan melakukan perkawinan.

b. Adanya wali dari pihak calon pengantin wanita.

c. Adanya dua orang saksi.

d. Sighat akad nikah, yaitu ijab qobul yang diucapkan oleh wali atau wakilnya dari pihak wanita, dan dijawab oleh calon pengantin lakilaki. Sedangkan syarat-syarat perkawinan merupakan dasar bagi sahnya pernikahan. Apabila syaratsyaratnya terpenuhi, maka perkawinan itu sah dan menimbulkan adanya segala hak dan kewajiban sebagai suami isteri.

Pada garis besarnya syarat-syarat sahnya pernikahan itu ada dua:

a. Calon mempelai perempuannya halal dinikahi oleh laki-laki yang ingin menjadikannya isteri. Jadi, perempuannya itu bukan merupakan orang yang haram dinikahi, baik karena haram dinikahi untuk sementara maupun untuk selama-lamanya.

b. Akad nikahnya dihadiri para saksi. Jadi tradisi perkawinan yang ada di masyarakat Samin jelas telah keluar dari syarat maupun rukun nikah yang ada sebagaimana yang telah dijelaskan di atas.

Dilihat dari syarat-syarat sah pernikahan tentu dalam tradisi masyarakat Samin sudah dapat kategorikan memenuhi. Ada calon mempelai pria dan wanita, serta dihadiri oleh saksi yang terdiri dari tetangga dan kerabat sendiri. Namun dalam Islam, tradisi pasuwitan sebagai legalitas pernikahan masyarakat Samin tentu bertolak belakang. Menurut pandangan Islam ada beberapa pemikiran, di antaranya menurut Umar (1985 : 152-153).

a. Al 'urf al fasid adalah kebiasaan yang bertentangan dengan dalildalil syara' dan kaidah-kaidah dasar yang ada dalam syara'. Misalnya, kebiasaan yang berlaku di kalangan pedagang dalam menghalalkan riba, seperti peminjaman uang antara sesama pedagang. Tradisi pasuwitan sebagai legalitas pernikahan masyarakat Samin ini bertentangan dengan dalil-dalil syara' dan kaidah-kaidah dasar yang ada dalam syara', menghalalkan yang haram dan mengharamkan yang halal.

b. Urf Fi'li yaitu kebiasaan yang berlaku dalam bentuk perbuatan. Tradisi pasuwitan yang ada pada masyarakat Samin ini merupakan tradisi yang berbentuk perbuatan 


\section{Ali Damsuki}

yakni menikahi pengantin putri tanpa adanya akad atau ijab qobul di depan para saksi dan berbuat intim dengan pengantin putri.

c. Urf Khusus yaitu 'urf yang hanya berlaku pada tempat masa atau keadaan tertentu saja. Tradisi pasuwitan yang ada di masyarakat Samin ini hanya berlaku di masyarakat Samin itu sendiri.

\section{Pernikahan Islam Masyarakat Samin}

Tradisi yang melekat pada masyarakat Samin seperti pasuwitan, dan tahapantahapan pernikahan lainnya memang sulit untuk diubah. Namun para da'i mencoba untuk mengubah pola pikir masyarakat Samin secara Islami. Metode dakwah yang digunakan salah satunya ialah melakukan pernikahan dengan akultutrasi budaya, antara laki-laki Islam dengan perempuan dari masyarakat Samin. Hal ini tentu dilatarbelakangi oleh pernikahan masyarakat Samin yang lebih mengutamakan komunitasnya sehingga dapat mengajarkan nilai-nilai sedulur sikep lebih mudah (Trianingsih, dkk, 2017: 45).

Pernikahan Islam dengan Samin sudah ada sejak dahulu, karena sudah ada pasangan keluarga yang dulu pada awalnya pihak istri berasal dari Samin, menikah dengan orang Islam dan sekarang sudah memiliki cucu. Keluarga tersebut sudah mengikuti ajaran agama Islam karena tinggal di kampung Islam. Pernikahan antara masyarakat Samin dan orang Islam awalnya mendapat penolakan dari pihak Samin. Begitu juga pihak Islam tidak setuju dengan pernikahan tersebut. Masingmasing pihak memiliki alasan tersendiri. Pihak Samin memiliki alasan seperti yang sudah dijelaskan di atas dan pihak Islam memiliki alasan bahwa masyarakat Samin sudah terkenal dengan ajarannya yang dipegang teguh dan juga tidak beragama Islam. Citra negatif dari masyarakat terhadap masyarakat Samin sudah menyebar luas sehingga pihak Islam dalam menjaga nama baiknya tidak mau berurusan dengan pihak Samin (Trianingsih, dkk, 2017: 59).

Proses akulturasi budaya melalui dakwah Islamiyah mulai datang dan memasuki masyarakat Samin. Proses islamisasi pun mulai bergerak melalui pernikahan Islam masyarakat Samin. Dakwah tidak menutup kemungkinan ada di keluarga masyarakat Samin yang menikah dengan orang Islam. Dakwah tersebut bisa dilakukan dengan jalan dakwah bil hal atau fardiyah yaitu antara perorangan (satu dai dan satu mad'u atau lebih) dalam kehidupan rumah tangganya pasca menikah. Nuansa dakwah tersebut sudah mulai terasa pada awal pernikahan dan pasca pernikahan dengan menyisipkan nilai-nilai keislaman dalam tiap aktivitas keluarganya (Trianingsih, dkk, 2017, 63).

Adapun tahap pernikahan secara Islam pada masyarakat Samin yang menikah dengan orang non-Samin Islam yaitu (Trianingsih, dkk, 2017: 64):

1. Lamaran, adalah tahap sebelum dilangsungkan pernikahan. Pihak orang tua dari mempelai laki-laki datang ke rumah calon mempelai perempuan. Biasanya Ibu dari calon mempelai laki-laki memakaikan cincin ke jari calon mempelai perempuan (calon menantu) sebagai tanda bahwa calon mempelai perempuan sudah dilamar atau dipinang oleh anak lelakinya.

2. Syahadat, adalah tahap di mana pihak Samin di-Islamkan yaitu dengan cara 
Konsep Pernikahan Masyarakat Samin...hal.102-118

di-syahadatkan terlebih dahulu Islam. Momen inilah yang dapat sebelum akad berlangsung. Pengislaman tersebut bisa dilakukan di tempat akad maupun satu minggu sebelum akad berbarengan dengan pengecekan kelengkapan administrasi pernikahan di KUA.

3. Akad nikah, adalah ijab qobul yang dilaksanakan oleh mempelai laki-laki dengan penghulu. Akad nikah dilakukan seperti akad nikah pada umumnya. Bagi mempelai perempuan apabila berasal dari kalangan Samin maka tidak bisa menggunakan wali Bapak kandungnya melainkan menggunakan wali hakim sekalipun Bapak kandungnya masih hidup.

4. Doa, biasanya setelah akad nikah diakhiri dengan doa oleh Modin dengan harapan agar pernikahan tersebut dapat menjadi keluarga yang sakinah, mawaddah, warahmah.

\section{Peran Modin Desa}

Kaur Kesra/Modin dalam struktur pemerintahan desa tugas pokoknya selain secara struktural berdasarkan perundangan juga memfasilitasi warga dalam pelayanan kematian (memandikan, mengkafani, mengimami salat jenazah, mentalqin pascapemakaman), dan memimpin doa pasca-kematian. Selain itu, modin bertugas membimbing calon pengantin non-Islam yang akan melakukan nikah secara Islam dengan ijab qabul di hadapan penghulu KUA.

Bagi warga Samin (Rosyid, 1998: 237), dalam proses perkawinannya secara Islam di hadapan penghulu KUA, modin berperan utama dalam mengajarkan bacaan syahadatain dan mengenalkan syariat

diperankan modin sebagai pendakwah bagi Samin yang muallaf sebelum akad nikah dan setelahnya. Bila modin memahami perannya sebagai pendakwah maka pascaakad nikah bimbingan Islam dapat dilanjutkan pada si muallaf (eks-Samin). Dakwah bil hal dengan pendekatan kultural dan struktural menjadi salah satu upaya mad'u saat dihadapkan dengan kebudayaan (culture) masyarakat Samin yang cenderung "mengagungkan" sebuah budaya, seperti halnya perkawinan tanpa melibatkan KUA, upacara kematian yang cenderung non-humanis, dan lain sebagainya. Proses dakwah Islamiyah dengan pendekatan kultural memberikan solusi bagi para da'i dalam menyebarkan agama Islam.

Dakwah kultural ini memiliki esensi untuk mengubah pola pikir dan prilaku yang cendrung "kolot" pada masyarakat Samin. Dakwah kultural mencoba memberikan nilai-nilai ke-Islaman yang dengan pendekatan budaya, tanpa harus menghilangkan esensi kebudayaan tersebut. Proses akulturasi ini tentu berjalan bertahap sesuai dengan kondisi masyarakat Samin sebagi mad'u. Kebudayaan masyarakat Samin mulai berubah dengan datangnya Islam. Kondisi tersebut dapat dilihat dari kebudayaan yang terarahkan pada sisi Islam.

Dalam proses upacara pernikahan, pihak KUA dan Departemen Agama mulai terlibat. Hal tersebut dilakukan agar secara agamis, ritual tersebut mendapatkan sebuah restu sebagai legalitas dan tercatat oleh kementian agama dalam administarsi serta diakui oleh negara. Dalam konteks keIslaman, tradisi yang dianjurkan tidak terlalu rumit, sebab Islam merupakan agama yang memberikan kemudahan dalam

Islamic Communication Journal Volume 4, Nomor 1, Januari-Juni $2019 \mid 115$ 


\section{Ali Damsuki}

menjalankan kewajiban bagi hambanya. Hal ini dijelaskan pula dalam al-Qur'an surat At- Thaha $20: 20$ );

"Kami tidak menurunkan Al-Qur'ân ini kepadamu agar kamu menjadi susah" [Thaha 20:2].

Misalnya dalam upacara perkawinan, umat muslim dibebaskan memilih pasangan yang ia cintai. Pra-pernikahan dalam Islam tidak dibatasi wilayah, tanggal lahir (weton), hal lainnya yang berkaitan dengan berbagai hal mistis lain yang ada pada pasangan calon pengantin, kecocokan dalam syariat Islam lebih diutamakan dan saat upacara pernikahan tidak terlalu mengedepankan hal mistis. Islam hanya memberikan wilayah pada syarat dalam pernikahan seperti halnya ada kedua belah pihak pengantin yang saling mencintai, wali, ijab-qabul, dan lain sebagainya.

\section{KESIMPULAN}

Kebudayaan dalam masyarakat Samin memiliki karakterisrik yang unik dan patut untuk dikaji. Problematika paradigma, sosial-ekonomi tentu menjadi hal yang tidak dapat dinafikan dalam mewarnai citra masyarakat Samin sendiri. Mulai dari kebudayaan yang "aneh" hingga pola pikir yang cenderung non-doktriner. Inilah sisi dinamika unik pada masyarakat Samin.

Namun dalam konteks keagamaan, kondisi tersebut perlu diluruskan. Sebab, Islam tidak mengajarkan sikap induvidualisme kelompok dan ajaran-ajaran lainnya yang dianggap kurang sesuai dalam sisi ke-Islaman. Hal ini tentu menjadi tugas dan tanggungjawab kita sebagai pendakwah. Dalam konteks ini, upaya memahami masyarakat Samin dengan kultur kebudayaan yang unik perlu pendekatan dakwah secara kultural, yaitu melalui akulturasi budaya (Aziz, 2004: 56). Akulturasi budaya ini tidak akan menghilangkan esensi budaya yang sudah ada, akan tetapi perlu "bumbu" nilai-nilai ke-Islam-an. Hal tersebut dilakukan agar masyakat Samin dapat belajar ke-Islaman melalui kebudayaan yang sudah ada.

Proses akulturasi budaya pernikahan masyarakat Samin dengan budaya Islam mulai dilakukan oleh para pendakwah melaui berbagai macam metode dakwah, di antaranya dengan dakwah bil hal atau fardiyah secara prorangan) dan dakwah struktural dengan pendekatan budaya. Dakwah tersebut dilakukan melalui pernihakan Islam antara masyarakat Samin dengan non-Samin yang lebih didominasi oleh pihak laki-laki sebagai muslim. Hal ini bertujuan untuk meng-Islamkan pihak perempuan yang menganut agama Samin.

Selai itu, dakwah struktural dilakukan oleh para kaur atau modin desa yang Islam. Modin desa ini akan membantu proses pernikahan Islam secara administrasi, tercatat dan diakui oleh negara secara hukum. Inilah salah satu proses perubahan akulturasi budaya yang selama ini terjadi pada masyarakat Samin sebagai salah satu pendekatan dakwah kultural.

\section{DAFTAR PUSTAKA}

Alexander, Loius. 2014. "Kebudayaan Suku Samin" .http://louisalx.blogspot.com/2014/ 03/kebudayaan-suku-samin.html. diakeses 25 Februari 2019.

Aziz, Moh. Ali. 2004. Ilmu Dakwah. Jakarta: Kencana. 
Konsep Pernikahan Masyarakat Samin...hal.102-118

B, Sakareeya. 2014. "Pendekatan Dakwah Kultural dalam Mayarakat Plural", Jurnal Dakwah Tabligh, Volume 15 Nomor 2 UIN Allaudin : Makassar.

Bambangsoe. 2018. "Pasuwitan Masyarakat

Samin".https://steemit.com/local/ @ bambangsoe/pasuwitan. diakeses 25 Februari 2019.

Departemen Agama. 2015.Mushaf AlQur'an dan Terjemahannya. Depok: Al- Huda.

Diah Ayuningrum. 2017. "Akuturasi Budaya Cina dan Islam dalam Arsitektur Tempat Ibadah di Kota Lasem Jawa Tengah", Jurnal Sabda (Kajian Kebudayaan) Volume 12 Nomor 2 .Undip : Semarang.

DOI: https://doi.org/10.14710/sabd a.12.2.122-135

Hamzah Junaid. 2013. "Kajian Kritis Akulturasi Islam dengan Budaya Lokal", Jurnal : Sulesana Volume 8 Nomor. 1. Makassar : UIN Alaludin Makassar.

DOI: https://doi.org/10.24252/jdt.v $\underline{15 \mathrm{i} 2.349}$

Kementerian Agama. 2012. UndangUndang Republik Indonesia Nomor 1 Tahun 1974 tentang Pernikahan. Bandung : Citra Umbara.

Kementerian Agama. 2013. UndangUndang Republik Indonesia Nomor 1 Tahun 1974 tentang Pernikahan dan Kompilasi Hukum Islam, Cet. 3. Bandung: Citra Umbara.
Kodiran, 1998. " Akulturasi sebagai Mekanisme Perubahan Kebudayaan",Jurnal Humaniora Nomor 8. Yogjakarta : Universitas Gajah Mada.

Kurnia Syah P, Dedi. 2016. Komunikasi Lintas Budaya; Menahami Teks Komunikasi, Media, Agama dan Kebudayaaan Indonesia. Bandung : Simbiosa Rekatama Media.

Laksanto Utomo, Stefanus.2013.Budaya Hukum Masyarakat Samin. Bandung : PT. Alumni.

Muhammad Taufiq dan Anis Tyas Kuncoro. 2006. "Pasuwitan sebagai Legalitas Perkawinan : Telaah Hukum Islam terhadap Perkawinan Suku Samin di Kabupaten Pati", Jurnal Ulul Albab (Jurnal Studi dan Penelitian Hukum Islam), Volume. 01 Nomor. 02. UNNISULA Semarang : Semarang.

Mukoyimah. 2013. "Theologi Masyarakat

Samin di Blora (Studi Kasus Masyarakat Samin di Blora)". Semarang : LP2M UIN Walisongo Semarang.

Poerwanto, Hari. 2010. Kebudayaan dan Lingkungan dalam Perspektif Antropologi. Yogyakarta : Pustaka Pelajar

Rofiq, Ahmad. 2010. Hukum Islam di Indonesia. Jakarta : PT. Sinar Grafika.

Rosyid, Moh. 2014. "Objek Dakwah yang Ternafikan (Studi Kasusu Pada Komunitas Samin)"Jurnal Dakwah Volume .XV, Nomor. 2.Kudus : UIN Walisongo Semarang. 
Ali Damsuki

Sarjono.1998. "Adat Perkawinan

Masyarakat Samin di Desa Tapelan

Kecamatan Ngaro Kabupaten

Bojonegoro", Jurnal Dakwah;

Bojonegoro : Panitia Penggali dan

Penyusun Sejarah.

Sulthon, Muhammad. 2003. Menajawab

Tantangan Zaman Desain Ilmu

Dakwah Kajian Ontologis,

Epistimologis, dan Aksiologis Cet

I. Yogjakarta : Pustaka Pelajar.

Umar, Muin. 1985. Ushul Fiqh 1. Jakarta :

Direktorat Jendral Pembinaan

Agama Islam Departemen Agama

RI.

Witter Turner, Victor. 1966. The Ritual

Process: Strukture and Anti-

Structure. New York: Cornell

University Press.

Zulfi Trianingsih, dkk. 2017.“Dakwah

Fardiyah melalui Pernikahan

Secara Islam pada Masyarakat

Samin (Sedulur Sikep) di Dusun

Bombong Baturejo Kecamatan

Sukolilo Kabupaten Pati", Jurnal

Ilmu Dakwah, Volume. 37 Nomor

1.

$118 \mid \begin{aligned} & \text { Islamic Communication Journal } \\ & \text { Volume 4, Nomor 1, Januari-Juni } 2019\end{aligned}$ 